\section{Status of Moerisia lyonsi Boulenger and Related Hydroids}

LAST year, when considering evolutionary trends in capitate hydroids and medusæ ${ }^{1}$, I was astonished by the remarkable similarity between some of these forms (Euphysa hydroids and Sarsia medusæ) and the hydroid and meduse of Moerisia lyonsi Boulenger ${ }^{2}$. The latter and related species of the family Moerisiidae have for some time been placed in the Limnomedusa $^{3}$, an order which includes such diverse forms as Proboscidactyla (Lar, the posturing polyp of Gosse) and Craspedacusta (the freshwater medusa).

Consideration of the important features of the Moerisiidae common to other Limnomedusae revealed these were: a quadrate stomach, tentacles which were either hollow or had an endodermal core consisting of more than a single row of cells, and the semblance of an endodermal root in the tentacles of the medusa ${ }^{4}$. These characters in themselves are not enough to warrant the separation of the Moerisiidae from the Capitata (with which their morphological characteristics strongly suggested they belonged) and I sought for additional links with other Limnomedusae. It was thought that the cnidome (the nematocyst armature) might reveal more positive evidence in favour of Limnomedusan affinities, but the three best-known species ${ }^{5}$ have a trienidome consisting of stenoteles, desmonemes and atrichous haplonemes ${ }^{6}$. This grouping of nematocyst types is essentially a capitate one, which is, moreover, distinct from the nematocyst pattern in the other two Limnomedusan families. The quadrate stomach of the medusa cannot be regarded as more than a variant of the basic pattern seen in the Capitata as its gonad is continuous and unbroken. The other two characteristics mentioned could arise independently in almost any family of medusae, and are probably far less significant than evidence based on nematocysts. For these reasons, which will be more fully discussed elsewhere, the family Moerisiidae is placed in the sub-order Capitata of the order Anthomedusae.

British Museum (Natural History),

$$
\text { W. J. REES }
$$

London, S.W.7. July 1.

${ }^{1}$ Rees, W. J., Bull. Brit. Mus., Zool., 4, 453 (1957).

${ }^{2}$ Boulenger, C. A., Quart. J. Micr. Sci., 53, 357 (1908).

${ }^{3}$ Kramp, P. L., Zool. Anz. Leipzig, 122, 103 (1938).

- Kramp, P. L., Vidensk. Medd. Naturh. Foren., 103, 503 (1939).

${ }^{5}$ Picard, J., Bull. Inst. Oceanogr. Monaco, 994, 1 (1951).

B Valkanov, A., Arb. Biol. Stat. Varna, 18, 33 (1954).

\section{Stimulation of Sclerotium Germination in Sclerotium cepivorum Berk.}

EarLIER work by Scott ${ }^{1}$ demonstrated the inability of $S$. cepivorum, the cause of white rot disease of onions, to grow or survive, in soil, in the form of mycelium, and focused attention on the biology of its sclerotia, which are produced in large numbers on the base of infected plants.

Sclerotia from cultures grown for six weeks on sand-maize-meal slopes at $20^{\circ} \mathrm{C}$. were shown to persist in undisturbed field soil for at least three years in the absence of the host plant. Using as inoculum sclerotia which had been buried for less than two months in soil, no infection occurred but there was heavy infection of onion seedlings inoculated with aclerotia which had been buried for longer periods.
Table 1. Percentage Germination of Sclerotia in Soll and

\begin{tabular}{|c|c|c|c|}
\hline Medium & $\begin{array}{l}\text { Water holding } \\
\text { capacity } \\
\text { (per cent) }\end{array}$ & $\begin{array}{l}\text { With }(+) \\
\text { Without }(-) \\
\text { onions }\end{array}$ & $\begin{array}{c}\text { Germination } \\
\text { (per cent) }\end{array}$ \\
\hline $\begin{array}{c}\text { Soil } \\
\text {," } \\
\text {,' } \\
\text { Sänd } \\
\text { ", } \\
\text {," }\end{array}$ & $\begin{array}{l}60 \\
60 \\
40 \\
40 \\
60 \\
60 \\
40 \\
40\end{array}$ & $\begin{array}{l}\frac{+}{ \pm} \\
\frac{ \pm}{+} \\
\pm\end{array}$ & $\begin{array}{r}83 \cdot 3 \\
0.0 \\
64: 6 \\
0.0 \\
62.5 \\
0.0 \\
45 \cdot 8 \\
0.0\end{array}$ \\
\hline
\end{tabular}

Accordingly, sclerotia used in germination experiments were taken from soil after six months burial.

Onion seedlings were inoculated, before being transplanted singly into tubes of soil, at 40 and 60 per cent water-holding capacity, by placing a sclerotium between the roots at the base of the bulb. On lifting the infected plants it was possible to see that the sclerotia had germinated characteristically by the formation of a plug of hyphæ which emerged after the rupture of the rind. In experiments of this kind levels of germination of sclerotia averaged 60-92 per cent, whereas in the control tubes without onions, germination was usually 0 per cent, and, rarely, up to 15 per cent.

In further experiments, moist nylon strips measuring $11 \mathrm{~cm} . \times 2.5 \mathrm{~cm}$. were placed inside $4 \mathrm{in} . \times 1 \frac{1}{4}$ in. glass specimen tubes, in contact with the glass, near the top. Sclerotia were placed in a ring between glass and nylon at the rate of twelve sclerotia per tube. In half the tubes twenty-four white Lisbon onion seeds were similarly placed $1 \mathrm{~cm}$. above the sclerotia. Soil or sand was then added to the tubes and kept at a constant water-holding capacity, at laboratory temperature. After eight weeks the levels of sclerotium germination were recorded (Table 1). Each value is an average of four replicates.

That the stimulatory effect of onions was not dependent upon contact between sclerotium and root was indicated by the fact that many of the germ. inating sclerotia were up to $1 \mathrm{~cm}$. distant from onion roots.

Using onion seedlings which were germinated on moist filter paper in Petri dishes, 100 per cent germ. ination of sclerotia occurred when they were placed in contact with any part of roots which had previously been damaged by needle pricking. On undamaged roots there was $97 \cdot 5,47.5$ and 57.5 per cent germination of sclerotia placed, respectively, on root tips halfway between tip and base, and on base of bulb. Sclerotia placed on moist filter paper in Petri dishes did not germinate.

The addition of water extracts of roots of onion, shallot, and leek also had a marked stimulatory effect on the germination of sclerotia in soil. Quoting the results of one particular experiment, average germination figures of $86 \cdot 7,93 \cdot 3$ and $73 \cdot 3$ per cent were obtained, respectively, with extracts of onion, shallot and leek. No germination occurred, however, using extracts of roots of cabbage, brussels sprout and barley, or when distilled water alone was added.

These investigations are proceeding with the object of isolating and identifying the stimulatory substance. J. R. Coley-Smith

Department of Botany,

University of Birmingham, Birmingham 15.

${ }^{1}$ Scott, M. R., Ann. App. Biol., 44, (4), 576 (1956). 